\title{
The Influence of Legal Theory on the All-Round Development of Contemporary College Students
}

\author{
Yan-Xia WANG \\ Xi'an Institute of Finance and Economics Xingzhi College Distinct addresses: 57 Di Zhai Road, \\ Shannxi Xi'an 710038, China \\ email:1195810433@qq.com
}

Key words: Legal theory; All-round development of college students; National rejuvenation

\begin{abstract}
This paper mainly discusses the influence on the legal theory of contemporary college students' all-round development. Through investigation and research, we can understand the role of the law in promoting the development of college students and the relationship between the legal and philosophical theories of the all-round development of contemporary college students, in order to reveal the influence of contemporary legal theory of all-round development of students. The aim of the social development is the all-round development of people conversely, the comprehensive development and to promote the development of the society, which are connected with each other who rely on each other, no less a part of who the dialectical theory. The field of comprehensive development of contemporary college student all-round development of human beings, the research of the comprehensive development of the contemporary the all-round development of college students to provide a theoretical basis and legal theory for the development of contemporary college students play a decisive role. Since eighteen, President Jinping Xi put forward to realize the great rejuvenation of the Chinese nation China dream, emphasized the revival of the nation and the country's overall development, the author believes that the comprehensive development of the development to a certain extent we depend on the state of college students; because college students are the new force to master knowledge, these knowledge including their major theoretical knowledge and other knowledge, the development of the knowledge of our national revival and the country to build to a certain extent, so how to guide The comprehensive and healthy development of contemporary college students? What kind of influence does the legal theory have on the all-round development of college students? It is the gist of this article. With the development of economic globalization and multi polarization of the world structure, the human society experienced a hitherto unknown development scene, the rapid development of science and technology, when it was transformed into productivity, promote the development of global economy, a real problem in front of people, in order to develop for what? But Marx's philosophical answer to this question, Marx philosophy epistemology view, understanding the world in order to transform the world, people change the world's purpose is to better benefit the world, that is to say in order to achieve the comprehensive development of each person. Then, the development theory of the whole society can't be separated from the research and outlook of the all-round development of contemporary college students. This article discusses the influence of the legal theory on the development of college students. This study will show the role of the development of college students in promoting social development and its importance to the development of college students and their influence
\end{abstract}

\section{Research Status of Human's Overall Development}

\section{The Current Situation of Foreign Research on the All-Round Development of Human Beings.}

In ancient Greece, the comprehensive development of their own people have needs, these needs from the theories of philosophy is a kind of perceptual knowledge from the development of cognitive representations, they have been aware of the existence of human being; finally rise to the understanding of the ancient Greek philosophers rational, this time they stress harmony the consistency of human development. One thousand years of medieval Europe, Christian theology has 
become all the guidance of thought, some thinkers thought for the liberation of humanity's Renaissance is mainly against theology and religious oppression of humanity, affirms human dignity and value rationality, that people desire, calling for people They should be the pursuit of freedom, equality, fraternity and rational thinking. The comprehensive development of Enlightenment thinkers on the further, Rousseau believes that with the development of civilization, people's morality is in decay, civilization is not the ideal of freedom and peace to the people, but the struggle and oppression. He considered legal countries only is a product built on the basis of people's free will of the social contract, the human to political freedom and equality in law instead of the natural state of freedom and equality, rationality instead of instinct, the freedom and equality of the denial of denial, humanity is raised to a higher stage.

\section{The Domestic Research Situation of the All-Round Development of Human Beings.}

The current situation of human overall development in China is mainly about Mao Zedong's all-round development thought and Deng Xiaoping's all-round development thought. These theoretical studies are the inheritance and development of Marx's theory --- human's all-round development theory. It is the product of the comprehensive development theory of Marx and the actual situation of China and the combination of Chinese traditional culture. They are emphasizing the all-round development of morality of human, this theory is aimed at young students' development .College students are required to take part in physical labor, so that education and production, mental work and physical labor are combined, which is of great significance for promoting the all-round development of College Students. Deng Xiaoping proposed the development of material civilization and spiritual civilization, cultivating national people do that have ideals, morality, culture, discipline "of the citizen. Three representatives, Scientific Outlook on Development, and Xi Jinping's speech in the human development, especially the comprehensive development of human view is very important, which is the inheritance and development of Marx's China the above theoretical importance of the comprehensive development of the discussion from various fields, according to the above theory can be seen the importance of all-round development of human beings, as an important force in national development, college students bear more social responsibility, their all-round development is closely linked with the development of the country.

\section{The Role of All-Round Development of Human Beings in the All-Round Development of Contemporary College Students}

\section{The Development of College Students Situation}

The contemporary college students in an era of rapid development of the society and enjoy the material conditions are getting better, but their quality of life and lifestyle is not as material conditions that is increasing. Nowadays, in pre University have never experienced the collective life of university students more and more, many college students don't know how to live, some college students even their limited to personal life, ignoring the lives of people around them; some students put their heart locked up, what activities do not participate in, complain about the college life is not wonderful, boring, claiming the lonely, depressed and unsuccessful. Through Xi'an Institute of Finance and Economics Xingzhi school A survey report, which college as an example, a survey on College Students' psychology, a set of data which shows that some college students have no clear life goals and ideals, so that their thinking is in a free state is not regular themself own thoughts, there is no clear the goal of life, more and more college students with university life is not easy, so idle, wasting time four years of college. 90 students grow in the spring breeze of reform and opening up, full of hopes and dreams for their college life, they think of university life so smooth, and the reality is far from their imagination of so good. A relaxed learning environment has a strict credit requirements; also small society regularly staged in the society the traditional code of conduct; wearing clothes bachelor to graduate employment but the sweetness of pressure all suppressed. Therefore, college students should not only have prepare for success, but also have the courage to face setbacks. When the students' personal goals obstacles or major setbacks, calmly analyze the 
situation, timely adjustment of strategies, trying to get rid of the dilemma, to avoid psychological and behavioral disorders, for the healthy growth of each student is essential. Learn a certain legal theory of college students, not only to improve their knowledge, but also increase the useful knowledge to protect their own rights, to improve college students' comprehensive qualities and individual connotation play a multiplier

\section{The Role of All-Round Development of Human Beings in College Students}

To promote the comprehensive development of contemporary college students' all-round development, carry forward the Marx doctrine about the people, is to promote China's higher education to perfect a basic and long-term arduous task. Therefore, we should strengthen the comprehensive development of education on College Students' concern and attention, on the other hand to profound analysis from the root of the theoretical origin and foundation of promoting the ideological education in Colleges and universities of our country perfect, only seriously do right in theory and a clear understanding of Marx's theory of people's all-round development connotation, and on this basis to grasp the scientific and accurate use, can be fully play The comprehensive development of human beings plays an advanced role in cultivating college students' all-round development of Education.

With the deepening of China's reform of our country, especially in the various aspects of thought have severe impact, various ideas and challenges continue to emerge, more or less directly and indirectly affect college students' Outlook on life, values, world view of the pursuit, in their own conditions to change the situation, and brings forward the new the challenge of Ideological and political education reform of colleges and universities, the traditional and ordinary higher education idea and method has no way to adapt to the new requirements of the comprehensive development of the new century, the situation requires the high school of our country constantly improve and strengthen the education of contemporary college students' all-round development. Therefore, the comprehensive development of Marx's theory about the education of College Students' all-round development has certain effect, it has more practical significance. Education and legal theory combined with the development of Marx's philosophy in the economic globalization and multi polarization of the world students more rational theory and practical significance.

\section{The Influence of Legal Theory on the All-Round Development of College Students.}

In today's era of continuous improvement of the rule of law, the ability of university student to do things according to law needs to be further strengthened. You need to develop the habit of abiding laws, and know how to learn, obey the law and use it. Only university students grasp the legal theories, knowledge of the theory of civil law and criminal law theory, and the basic knowledge of law, and combining the practice to the theory the use of skilled, can college students in learning, life and job employment, distinguish between morality and law, freedom and discipline, correct understanding of the relation between democracy and legal system, know how to use legal weapons to protect their legitimate rights and interests, to consciously resist the "pornography" Erosion, self-awareness and various foreign reactionary organizations, all the Falun Gong organization to incite the penetration, split, subversion struggle. To safeguard the national political, economic and information security, to actively promote the national laws and policies of the party, to create a social atmosphere to act according to law due diligence. Grasp and study these theories can make knowledge of students in the society, able to cope with the complex environment, in order to meet the change danger into safety danger, setbacks continue to enhance their self-confidence that make themself become stronger, and constantly improve themselves-ability. A professional ability Talents have legal connotation of moral education to protect themself rather than go to the Dutch act when they met setbacks. It is a loss, to society and to their parents, such a person does not meet the national requirements of the development of contemporary college students, nor the social needs of the comprehensive development of talent.

To sum up, it is not difficult to see that the all-round development of college students can't be separated from the influence of philosophy, and the influence of the theory of law on it can't be 
separated.

\section{Reference}

1, Chen Lai $[<<$ the basic idea of Confucian educational thought $>>$, Journal of Peking University, 2005, 05;

2, He Yuhong, Confucian culture and ideological and political education of college students, Heilongjiang higher education research, 2009, 10;

3, Zhang Yongbo, Wang Yangtian. Development status, problems and Countermeasures of College Students' quality education. Friends of farm friends, 2010, 7;

4 , Shen Xiaoyan, $<<$ ways to strengthen the socialist core values education of college students $>>$ higher education, 2016, 2;

5, Ma Jing, [approach to the implementation of quality education for college students]. Journal of Shanxi Normal University (SOCIAL SCIENCE EDITION) 2011, 3 